\title{
Faktor - Faktor Yang Mempengaruhi Opini Audit Going Concern \\ Pada Perusahaan Sub Sektor Tekstil dan Garment Yang Terdaftar Di Bursa Efek Indonesia
}

\author{
Muhammad Wirandi Saputra ${ }^{1}$, Yasir Arafat ${ }^{2}$, Nurmala ${ }^{3}$ \\ ${ }^{1}$ Fakultas Ekonomi dan Bisnis Universitas PGRI Palembang, Cuman.cemen26@gmail.com \\ ${ }^{2}$ Fakultas Ekonomi dan Bisnis Universitas PGRI Palembang, yasirarafat@univpgri-palembang.ac.id \\ ${ }^{3}$ Fakultas Ekonomi dan Bisnis Universitas PGRI Palembang, nurmalabahamid@Gmail.Com
}

\begin{abstract}
This study aims to analyze market reactions to dividend announcements on the Indonesia Stock Exchange. The population in this study are companies that consistently announce dividends in the 2017-2019 period. The method used in determining the sample is the Literature Study and Documentation method so that as many as 29 issuers are obtained. Tests in this study using analytical techniques used to test significant levels of abnormal return are simple linear regression testing and $t$-test. The results obtained in this study are that the market reacts fluctuatively during the dividend announcement period (days $t-7$ to days $t+7$ ) with abnormal fluctuations marked. These results can be interpreted that the announcement of a dividend has no effect on market reaction on the Indonesia Stock Exchange.
\end{abstract}

Keywords: Abnormal Return, Dividend Announcement

\begin{abstract}
ABSTRAK
Penelitian ini betujuan untuk menganalisis reaksi pasar terhadap pengumuman dividen di Bursa Efek Indonesia. Populasi dalam penelitian ini adalah perusahaan yang konsisten mengumumkan dividen pada periode 2017-2019. Metode yang digunakan dalam penentuan sampel adalah metode Studi Pustaka dan diperoleh sebanyak 29 emiten. Pengujian dalam penelitian ini menggunakan teknik analisis yang digunakan untuk menguji tingkat signifikan abnormal return adalah pengujian regresi linier sederhana dan t-test. Hasil yang diperoleh dalam penelitian ini yaitu pasar bereaksi secara berfluktuatif pada saat periode peristiwa pengumuman dividen (hari t-7 sampai dengan hari $t+7$ ) dengan ditandainya fluktuatifnya abnormal return. Hasil tersebut dapat diartikan bahwa pengumuman dividen tidak berpengaruh signifikan terhadap reaksi pasar di Bursa Efek Indonesia.
\end{abstract}

Kata Kunci : Abnormal Return, Pengumuman Dividen

\section{A. PENDAHULUAN}

Investasi adalah penanaman ekuitas untuk satu atau lebih aktivas yang di miliki dan biasanya untuk waktu yang lama dengan tujuan mendapatkan keuntungan di massa yang akan datang (Sunariyah, 2011:04). Dalam melakukan transaksi investasi tersebut para investor harus mengikuti aturan yang sudah di tetapkan oleh lembaga yang menfasilitasi dan menjalankan transaksi dalam hal ini Bursa Efek. Di bursa efek yang menetapkan aturan ialah pemegang otoritas pasar modal, sehingga para penawar (emiten) tidak melakukan penawaran yang tidak masuk akal dalam penawaran di bursa efek. Bursa efek dapat dikatakan baik jika memberikan informasi yang dimana harga saham menggambarkan semua informasi keseluruhan mencangkup informasi di masa lalu.

Para investor yang bertransaksi di bursa efek memerlukan informasi untuk membuat suatu keputusan dalam memilih portofolio investasi yang menguntungkan. Hal tersebut sesuai dengan yang dikemukakan oleh Setyowati (2010:89) bahwa keputusan investasi di pasar modal memerlukan berbagai macam informasi 
termasuk di dalamnya informasi yang berhubungan dengan kinerja perusahaan dan informasi lainya yang bersifat teknikal. Informasi yang berhubungan dengan kondisi perusahaan umumnya ditunjukkan dalam laporan keuangan yang merupakan salah satu ukuran kinerja perusahaan. Salah satunya dengan melakukan penumuman deviden perusahaan, mengumumkan dividen merupakan salah satu upaya perusahan untuk memberi informasi yang di butuhkan para investor, sehingga menimbulkan reaksi pasar saham karena investor mempunyai gambaran bagaiman prospek perusahaan di masa yang akan datang.

Karena pengumuman deviden mengandung hal yang sangat penting mengenai prospek perusahaan dalam hal ini informasi dari perusahaan tempat yang akan dilakukan investasi. Seringkali pengumuman dividen di artikan sebagai informasi jika pasar bereaksi pada saat pengumuman yang terdapat di pasar. Informasi ini seringkali mempengaruhi keputusan yang diambil oleh para investor dan pasar merespon informasi demi mencari keseimbangan baru. Reaksi tersebut dapat berupa respon positif dan respon negatif.

Penelitian terhadap pengaruh pengumuman dividen masih mungkin untuk dikaji karena ada ketidak-konsistenan beberapa penelitian terdahulu. Jogiyanto (2015:623) menyatakan penelitian mengenai pengaruh sebuah peristiwa terhadap aktivitas perdagangan dilakukan melalui studi peristiwa (event study), yaitu merupakan studi yang mempelajari reaksi pasar terhadap suatu perisitwa (event) yang informasinya dipublikasikan sebagai suatu pengumuman.

Pada penelitian ini penulis memutuskan untuk memilih corporate action yaitu pengumuman dividen, disebabkan karena pengumuman dividen adalah perisitiwa yang rutin dibagikan setiap tahunnya dan dapat dicerna oleh investor yang pada akhirnya akan menciptakan reaksi pasar, serta pengumuman dividen sebagai gambaran kemajuan perusahaan di masa depan sebagai dasar pertimbangan investor untuk menanamkan modalnya.

\section{B. KAJIAN TEORI}

\section{Abnormal Return}

Motivasi utama investor menanamkan modalnya dalam suatu investasi adalah mendapatkan tingkat pengembalian (return) investasi yang optimal. Return merupakan tingkat keuntungan yang dinikmati investor atas suatu investasi yang dilakukannya. Return saham yang akanditerima oleh investor sangat dipengaruhi oleh jenis investasi yang dipilih. Untuk mengukur besarnya return yang akan diterima investor sehubungan dengan adanya peristiwa stock split diukur dengan adanya abnormal return yang diterima oleh investor.

Abnormal return merupakan selisih antara return yang sebenarnya (Actual Return) dengan return yang diharapkan (Expected Return) (Hartono, 2013). Tingkat keuntungan yang sesungguhnya merupakan perbandingan antara selisih harga saham periode sekarang dengan periode sebelumnya. Abnormal return yang positif menunjukkan tingkat keuntungan yang diperoleh lebih besar yaitu antara actual return dan expected return.

Berkaitan dengan peristiwa pemecahan saham, apabila terjadi abnormal return yang positif setelah pemecahan saham dapat memberikan keuntungan diatas normal pada investor dan sebaliknya jika terdapat abnormal return yang negatif menunjukkan bahwa keuntungan yang diperoleh dibawah normal. Uji efisiensi pasar modal yaitu dengan menganalisis return yang tidak normal (abnormal return) yang terjadi. Abnormal return merupakan kelebihan dari return yang sesungguhnya terjadi 
terhadap return normal. Studi peristiwa merupakan analisis return tidak normal (abnormal return) dari sekuritas yang mungkin terjadi disekitar pengumuman dari suatu peristiwa.

Dengan demikian return tidak normal (abnormal return) dapat dihitung dengan rumus (Jogiyanto, 2016) sebagai berikut :

Dimana :

$$
A R \text { it }=R \text { it }-E(R \text { it }
$$

AR it

: return tidak normal (abnormal return) saham i pada periode peristiwa ke- $t$

$\mathrm{R}$ it $\quad$ : return sesungguhnya (actual return) yang terjadi untuk saham ke i pada periode peristiwa ke- $t$.

$\mathrm{E}(\mathrm{R}$ it $) \quad$ : expected return saham ke i untuk periode peristiwa ke- $\mathrm{t}$.

Actual return (return sesungguhnya) merupakan keuntungan yang dapat diterima atas investasi saham pada suatu periode tertentu, secara matematis dapat dirumuskan (Jogiyanto, 2016) sebagai berikut :

Keterangan:

$$
\mathrm{Ri}, \mathrm{t}=\frac{P i, t-p i, t-1}{\mathrm{Pi}, \mathrm{t}-1}
$$

$\mathrm{Ri}, \mathrm{t} \quad=$ Return sesungguhnya yang terjadi untuk sekuritas ke-i pada periode peristiwa ke-t

$\mathrm{Pi}, \mathrm{t}=$ harga sekarang relatif

$\mathrm{Pi}, \mathrm{t}-1$ = harga sebelumnya 1

Sedangkan expected return yang harus diestimasi dengan menggunakan beberapa model estimasi (Hartono, 2013) antara lain :

A. Mean Adjusted Model

Model disesuaikan rata-rata (mean adjusted model) ini menganggap bahwa expected return bernilai konstan yaitu sebesar nilai rata - rata actual return sebelumnya selama periode estimasi, sebagai berikut :

Keterangan :

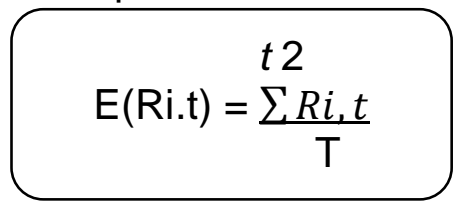

$E($ Ri.t $)=$ expected return sekuritas ke-i pada periode peristiwa ke-t

$\mathrm{Ri}, \mathrm{t}=$ actual return sekuritas ke-i pada periode peristiwa ke-t

$\mathrm{T} \quad=$ Lamanya periode estimasi.

Periode estimasi (estimation periode) umumnya merupakan periode sebelum peristiwa. Periode peristiwa (event period) disebut juga dengan periode pengamatan atau jendela peristiwa (event window).

\section{B. Market Model}

Perhitungan expected return dengan model pasar (market model) ini dilakukan dengan dua tahap, yaitu :

Membentuk model ekspektasi dengan menggunakan data realisasi selama periode estimasi. 
Menggunakan model ekspetasi ini untuk mengestimasi return ekspektasi di periode jendela.

> Model ekspektasi dapat dibentuk menggunakan teknik regresi OLS (Ordinary Least Square) dengan persamaan :

$$
E(R i t)=\alpha i+\beta i R m t+\varepsilon i t
$$

Keterangan :

$\mathrm{E}(\mathrm{Rit}) \quad=$ return ekspektasi sekuritas ke-i pada waktu $\mathrm{t}$

$\mathrm{Ai} \quad=$ intercept, independen terhadap Rmt

$\mathrm{Bi} \quad=$ slope, resiko sistematis, dependen terhadap Rmt

हit $\quad=$ kesalahan redisu sekuritas i pada periode estimasi ke $\mathrm{t}$

\section{Market Adjusted Model}

Model ini menganggap bahwa penduga terbaik untuk mengestimasi return suatu sekuritas adalah return indeks pasar pada saat tersebut. Dengan menggunakan model ini maka tidak perlumenggunakan periode estimasi untuk membentuk model estimasi, karena return sekuritas yang diestimasi adalah sama dengan return pasar.

Dimana :

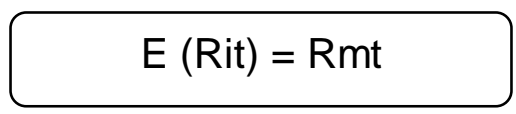

$E(R$ it $)$

= return ekspektasi sekuritas ke-i pada periode peristiwa ke-t.

Rmt $=$ return sekuritas pada waktu ke $-\mathrm{t}$.

\section{Kerangka Pemikiran}

Pengujian kandungan informasi dimaksudkan untuk melihat reaksi dari publikasi pembagian dividen. Jika publikasi tersebut mengandung informasi maka diharapkan pasar akan bereaksi pada waktu publikasi tersebut diterima oleh pasar. Reaksi pasar ditunjukkan dengan adanya perubahan harga saham. Reaksi perubahan harga saham biasanya diukur dengan menggunakan return sebagai nilai perubahan atau dengan menggunakan abnormal return. Jika digunakan abnormal return, maka dapat dikatakan bahwa suatu publikasi yang memiliki kandungan informasi akan memberikan abnormal return kepada pasar. Sebaliknya suatu publikasi yang tidak memliki kandungan informasi tidak memberikan abnormal return kepada pasar. Berdasarkan uraian diatas maka secara keseluruhan reaksi pasar terhadap kandungan informasi yang berkaitan dengan pengumuman kenaikan dan penurunan dividen ditunjukkan pada gambar berikut ini :

\section{Kerangka Pemikiran Teoritis}

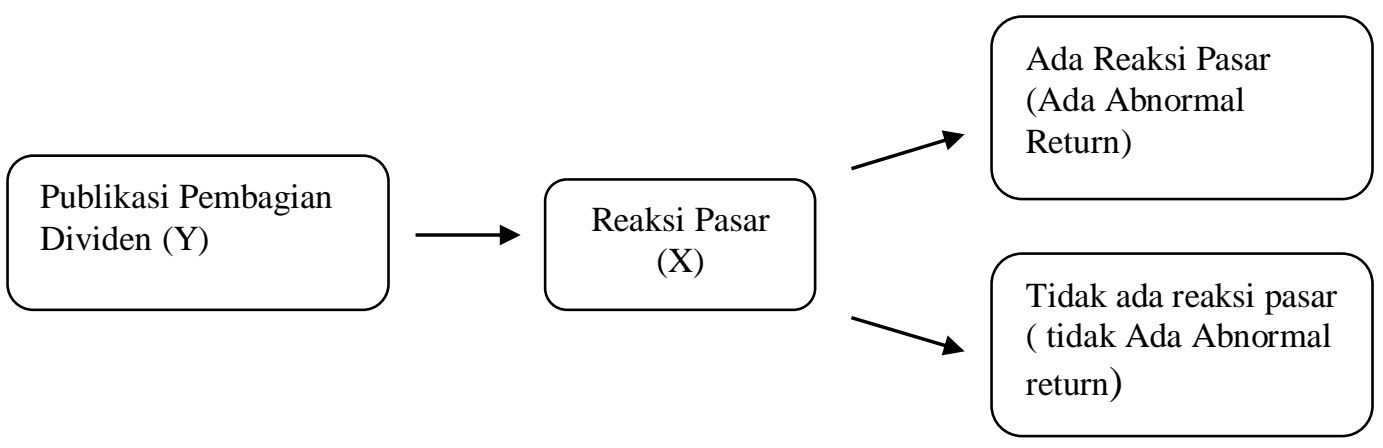




\section{Hipotesis Penelitian}

Menurut penelitian Mediyanto (2015) bahwa pemecahan saham akan memberikan pengaruh penilaian investor dalam pengambilan keputusan investasi, yang akan mengakibatkan adanya perbedaan dalam aktivitas perdagangan saham sebelum dan sesudah pengumuman. Bagi investor, pengumuman pemecahan saham dapat dianggap sebagai sinyal positif dari manajemen tentang prospek perusahaan di masa yang akan datang. Dengan demkian terdapat adanya perbedaan abnormal return saham antara sebelum. Dengan demikian hipotesis yang diajukan:

Ha: Reaksi pasar mempunyai pengaruh terhadap publikasi dividen di pasar modal Indonesia.

Ho: Tidak ada pengaruh dari reaksi pasar (investor) sesudah publikasi dividen di pasar modal Indonesia.

\section{METODE PENELITIAN}

Penelitian ini menggunakan metode penelitian kuantitatif yang masuk dalam kategori penelitian eksperimental dari pengujian teori Event Study, Sugiyono (2013) menambahkan penelitian eksperimen dapat diartikan sebagai metode penelitian yang digunakan untuk mencari pengaruh perlakuan tertentu terhadap yang lain dalam kondisi yang terkendalikan.

Objek penelitian ini terpusat pada reaksi dari pasar terhadap publikasi dividen yang mana untuk mengetahui reaksi tersebut harus mencari abnormal return beserta dengan actual return dan expected retun, berdasarkan penjelasan di atas, maka objek dalam penelitian ini adalah emiten-emiten yang tercatat di Bursa Efek Indonesia dan kosnsiten masuk dalam data indeks LQ45. Lokasi dalam pengambilan data pada penelitian ini yaitu di Bursa Efek Indonesia melalui Https://www.idx.co.id dan https://finance.yahoo.com/

Populasi untuk penelitian ini ialah 58 emiten yang ada dalam LQ 45 dan terdaftar di Bursa Efek Indonesia.kurun waktu 2017 - 2019. Berdasarkan kriteria, maka perusahaan yang memenuhi syarat masuk dalam sampel penelitian ini adalah sebanyak 29 perusahaan.

Teknik pengumpulan data menggunakan cara studi pustaka dan dokumentasi. Teknik pengumpulan data ini dilakukan dengan cara mencatat, mengumpulkan, dan menganalisis data saham perhari emiten-emiten yang tercatat di Bursa Efek Indonesia dan kosnsiten masuk dalam data indeks LQ45.

Pada penelitian ini telah ditentukan 2 variabel, yaitu variabel bebas atau variabel independen dan variabel terikat atau dependen. Variabel terikat atau dependen $(\mathrm{Y})$ merupakan variabel yang dipengaruhi atau yang menjadi akibat, karena adanya variabel bebas (Sugiyono, 2013). Variabel terikat pada penelitian ini yaitu Publikasi pembagian Dividen.Variabel bebas atau variabel independen (X). Menurut Sugiyono (2013) variabel bebas adalah "Merupakan variabel yang mempengaruhi atau yang menjadi sebab perubahannya atau timbulnya variabel dependen (terikat)". Variable bebas pada penelitian ini yaitu Abnormal Return.

\section{HASIL PENELITIAN}

\section{Perhitungan Actual Return}

Tahapan pertama dalam menghitung abnormal return adalah menghitung actual return atau return realisasi, yaitu merupakan keuntungan yang sesungguhnya terjadi atau keuntungan yang telah terjadi dengan perbandingan dari harga saham 
pada saat $t(P, t)$ dikurangi harga saham pada saat $t-1 \quad(P, t-1)$ ditambah dengan dividen pada saat $t$, kemudian dibagi dengan harga saham pada saat $t-1 \quad(P, t-1)$ dengan formula .

Selama periode peristiwa hasil yang didapat dalam actual return terdapat return yang positif, negatif dan nol. Actual return yang bernilai nol menandakan bahwa harga saham pada hari ke-t sama dengan return saham pada hari $t-1$, sedangkan actual return bernilai negatif menandakan bahwa terdapat penurunan return saham pada hari ke-t dengan hari t-1, dan actual return bernilai positif bahwa terjadi peningkatan pada return saham pada hari ke-t dengan hari t-1.

Pada 3 tahun periode peristiwa yang mana dalam penelitian ini ada 15 hari, terbagi 7 hari sebelum pengumuman, 1 hari sebagi event date dan 7 hari sesudah tanggal pengumuman dividen, dimana hasil yang didapat cenderung fluktuatif pada 3 tahun periode peristiwa, dan hasil yang di dapat sebanyak $37 \%$ hasil return saham bernilai negatif , $41 \%$ bernilai positif dan sebanyak $22 \%$ bernilai 0 .

Tabel Data Actual Return

Periode 2017-2019

\begin{tabular}{|c|c|c|c|c|}
\hline Hari t & Negatif & Nol & Positif & Jumlah \\
\hline-7 & 34 & 22 & 31 & 87 \\
\hline-6 & 28 & 28 & 31 & 87 \\
\hline-5 & 32 & 21 & 34 & 87 \\
\hline-4 & 32 & 22 & 33 & 87 \\
\hline-3 & 33 & 22 & 32 & 87 \\
\hline-2 & 34 & 19 & 34 & 87 \\
\hline-1 & 21 & 7 & 59 & 87 \\
\hline 0 & 29 & 20 & 38 & 87 \\
\hline 1 & 27 & 23 & 37 & 87 \\
\hline 2 & 32 & 18 & 37 & 87 \\
\hline 3 & 37 & 16 & 34 & 87 \\
\hline 4 & 32 & 18 & 37 & 87 \\
\hline 5 & 35 & 17 & 35 & 87 \\
\hline 6 & 39 & 18 & 30 & 87 \\
\hline 7 & 36 & 20 & 31 & 87 \\
\hline Jumlah & $\mathbf{4 8 1}$ & $\mathbf{2 9 1}$ & $\mathbf{5 3 3}$ & $\mathbf{1 3 0 5}$ \\
\hline Persentase & $\mathbf{3 7 \%}$ & $\mathbf{2 2 \%}$ & $\mathbf{4 1 \%}$ & $\mathbf{1 0 0 \%}$ \\
\hline
\end{tabular}

Sumber : (BEI, data diolah Excel, 2020)

\section{Perhitungan Excpected Return}

Penelitian ini menggunakan Market Model, Excpected return yang menggunakan Market Model diperoleh dengan cara intercept pada periode ke $\mathrm{t}$ ditambah slope ( harga keseimbangan resiko di pasar) pada periode ke t dan di kali dengan return saham pada periode ke t. Selama periode peristiwa terdapat nilai expected return positif dan negatif. Dari Tabel 4.2 terdapat hasil nilai expected return negatif sebesar $38 \%$ dan expected return positif $61 \%$, nilai expected return positif lebih besar dibandingkan dengan nilai expected return negatif, hal ini dapat menandakan bahwa terindikasi perdagangan di pasar modal sangat atraktif pada saat periode peristiwa. 
Tabel Data Expected Return Periode 2017-2019

\begin{tabular}{|c|c|c|c|}
\hline Hari t & Negatif & Positif & Jumlah \\
\hline-7 & 40 & 47 & 87 \\
\hline-6 & 30 & 57 & 87 \\
\hline-5 & 32 & 55 & 87 \\
\hline-4 & 34 & 53 & 87 \\
\hline-3 & 34 & 53 & 87 \\
\hline-2 & 32 & 55 & 87 \\
\hline-1 & 26 & 61 & 87 \\
\hline 0 & 31 & 56 & 87 \\
\hline 1 & 31 & 56 & 87 \\
\hline 2 & 36 & 51 & 87 \\
\hline 3 & 42 & 45 & 87 \\
\hline 4 & 36 & 51 & 87 \\
\hline 5 & 35 & 52 & 87 \\
\hline 6 & 38 & 49 & 87 \\
\hline 7 & 34 & 53 & 87 \\
\hline Jumlah & $\mathbf{5 1 1}$ & $\mathbf{7 9 4}$ & $\mathbf{1 3 0 5}$ \\
\hline Persentase & $\mathbf{3 9} \%$ & $\mathbf{6 1 \%}$ & $\mathbf{1 0 0 \%}$ \\
\hline
\end{tabular}

Sumber : (BEl, data diolah Excel, 2020)

\section{Perhitungan Abnormal Return}

Abnormal return diperoleh dengan cara mencari selisih antara actual return dan expected return. Berdasarkan perhitungan selama periode peristiwa, terdapat abnormal return yang bernilai postif maupun negatif. Actual return saham yang bernilai lebih besar daripada expected return yang diprediksi oleh investor akan menghasilkan nilai abnormal return yang positif, sedangkan nilai abnormal return yang negatif menunjukkan bahwa actual return saham nilainya lebih kecil dibandingkan dengan expected return. Pada Tabel 4.3 secara keseluruhan terdapat sebanyak 1305 nilai abnnormal return, dari nilai tersebut nilai abnormal return positif sebanyak 528 (40\%) sedangkan nilai abnormal return negatif sebanyak 777 (60\%).

Tabel Data Abnormal Return Periode 2017-2019

\begin{tabular}{|c|c|c|c|c|}
\hline \multirow{2}{*}{ Hari ke -t } & \multicolumn{3}{|c|}{ Abnormal return } & \multirow{2}{*}{$\begin{array}{c}\text { Average Abnormal } \\
\text { Return }\end{array}$} \\
\cline { 2 - 4 } & Negatif & Positif & Jumlah & 0.00170 \\
\hline-7 & 54 & 33 & 87 & -0.00210 \\
\hline-6 & 50 & 37 & 87 & -0.01193 \\
\hline-5 & 57 & 30 & 87 & -0.00408 \\
\hline-4 & 56 & 31 & 87 & -0.01081 \\
\hline-3 & 50 & 37 & 87 & -0.00653 \\
\hline-2 & 51 & 36 & 87 & 0.00543 \\
\hline-1 & 42 & 45 & 87 & -0.00799 \\
\hline 0 & 48 & 39 & 87 & -0.00241 \\
\hline 1 & 51 & 36 & 87 & -0.01149 \\
\hline 2 & 55 & 32 & 87 & -0.00044 \\
\hline 3 & 52 & 35 & 87 & 0.00527 \\
\hline 4 & 49 & 38 & 87 & 0.00069 \\
\hline 5 & 47 & 40 & 87 & -0.00639 \\
\hline 6 & 58 & 29 & 87 & -0.00306 \\
\hline 7 & 57 & 30 & 87 & \\
\hline Jumlah & 777 & 528 & 1305 & \\
\hline Presentase & $60 \%$ & $40 \%$ & $100 \%$ & \\
\hline Sumbern & (B) & \\
\hline
\end{tabular}

Sumber : (BEl, data diolah Excel, 2020) 
Pada penelitian ini didapat hasil Average abnormal return bergerak secara naik dan turun dikarenakan perubahan harga pasar. Pada gambar dibawah ini menggambarkan rata-rata abnormal return pada saat peristiwa pengumuman dividen berlangsung diperoleh pada saat $\mathrm{t}-7$ nilai rata-rata abnormal return sebesar 0.002 dan terjadi penurunan dari $\mathrm{t}-6$ sebesar $-0,002$ sampai dengan $\mathrm{t}-2$ sebesar $-0,007$, pada $\mathrm{t}-2$ dan $\mathrm{t}-1$ mengalami fluktuatif dan pada saat pengumuman dividen $\mathrm{t} 0$ mengalami penurunan sebasar $-0,008$ sampai dengan $t+3$, terjadi kenaikan pada $t+4$ sebesar 0,005 , serta hasil yang fluktuatif terjadi $t+5$ sampai dengan $t+7$. Pada gambar dibawah nilai tertinggi dialami pada $t-1$ dan $t+4$ sebesar 0,005 dan nilai terendah terjadi pada saat $t+5-0,012$.

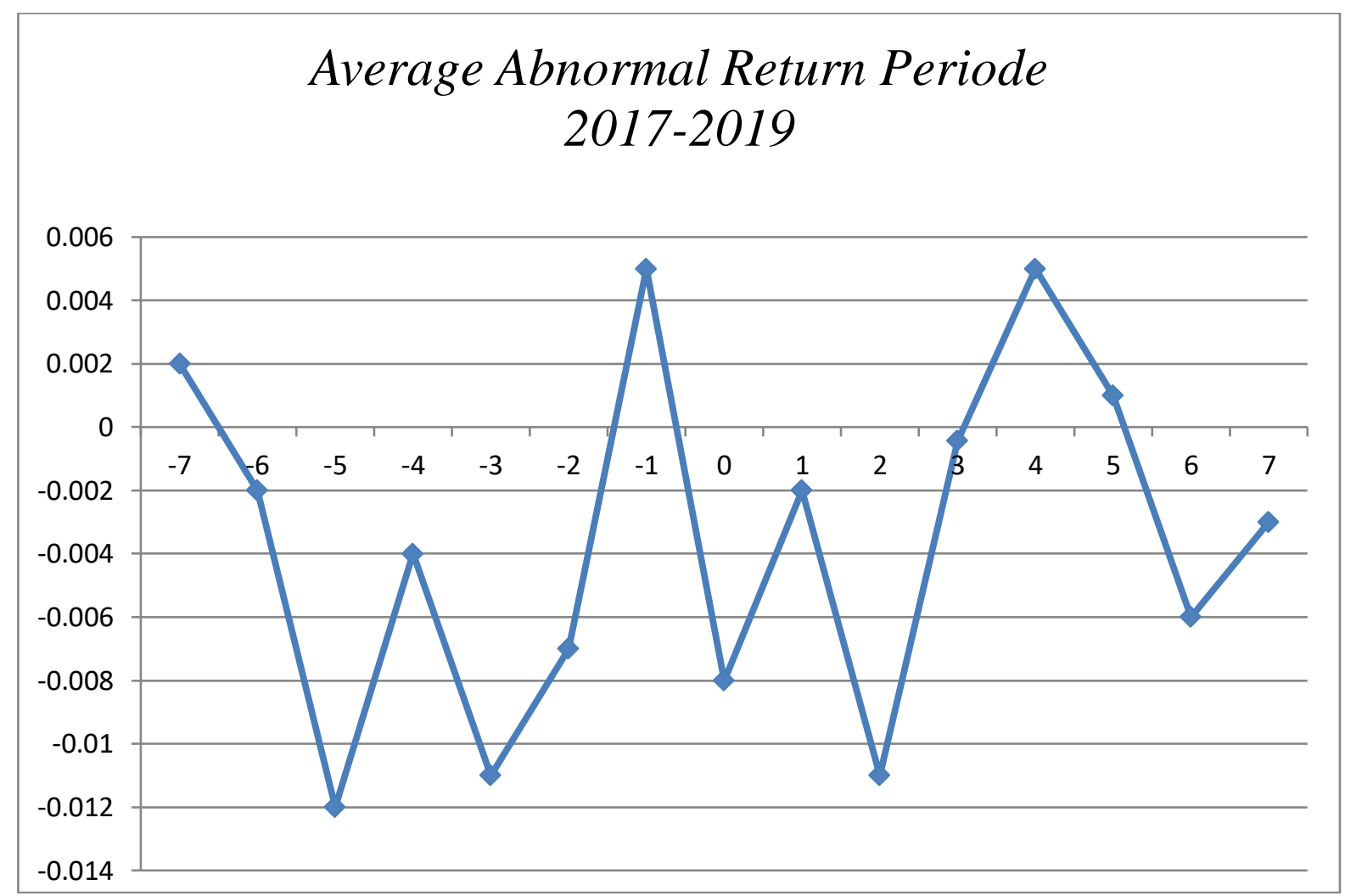

Gambar Grafik Average Abnormal Return pada saat peristiwa

Sumber : (BEI, data diolah, 2020)

\section{Uji Asumsi Dasar}

\section{Pengujian Data Linieritas}

Menurut Sugiyono (2013) uji linearitas dapat dipakai untuk mengetahui apakah variabel terikat dengan variabel bebas memiliki hubungan linear atau tidak secara signifikan. Kriteria yang berlaku adalah jika nilai signifikansi pada linearity > 0,05 , maka dapat diartikan bahwa antara variabel bebas dan variabel terikat terdapat hubungan yang linear. 
Tabel Hasil Uji Linieritas Variabel Data

ANOVA Tabel
\begin{tabular}{|lll|r|r|r|r|r|}
\hline & & $\begin{array}{c}\text { Sum of } \\
\text { Squares }\end{array}$ & df & $\begin{array}{c}\text { Mean } \\
\text { Square }\end{array}$ & \multicolumn{1}{c|}{$\mathrm{F}$} & Sig. \\
\hline$X * Y \quad$ Between Groups & (Combined) & 11,714 & 5 & 2,343 &, 293 &, 876 \\
& Linearity &, 390 & 1 &, 390 &, 049 &, 862 \\
& Deviation from & 11,324 & 4 & 2,831 &, 354 &, 832 \\
& Linearity & 8,000 & 1 & 8,000 & & \\
\hline & & 19,714 & 6 & & & \\
\hline
\end{tabular}

Sumber : (BEl, data diolah, 2020)

Dapat dilihat pada tabel diatas bahwa nilai deviation from linearity signifikan sebesar 0,832. Maka dapat disimpulkan bahwa variabel Independent dan variabel Dependent adalah linier, karena memenuhi dasar pengambilan keputusan $>0,05$ sehingga dapat dilakukan uji regresi linier sederhana.

\section{Regresi Linier Sederhana}

Menurut Sugiyono (2013), analisis regresi sederhana digunakan untuk mengetahui pengaruh antara dua variabel yang diteliti. Dalam Penelitian ini variabel terikat yaitu publikasi pembagian dividen dan variable bebas pada penelitian ini yaitu reaksi pasar (Abnormal Return).

Tabel Nilai Regresi Linier Sederhana

Coefficients $^{a}$

\begin{tabular}{|c|c|c|c|c|c|}
\hline \multirow[b]{2}{*}{ Model } & \multicolumn{2}{|c|}{$\begin{array}{l}\text { Unstandardized } \\
\text { Coefficients }\end{array}$} & \multirow{2}{*}{$\begin{array}{c}\text { Standardized } \\
\text { Coefficients } \\
\text { Beta }\end{array}$} & \multirow[b]{2}{*}{$t$} & \multirow[b]{2}{*}{ Sig. } \\
\hline & B & Std. Error & & & \\
\hline $\begin{array}{cc}1 & \text { (Constant) } \\
\mathrm{X}\end{array}$ & $\begin{array}{r}-2,406 \\
, 290\end{array}$ & $\begin{array}{r}1,618 \\
, 912\end{array}$ & 141, & $\begin{array}{r}-1,487 \\
, 318\end{array}$ & $\begin{array}{l}, 197 \\
, 764\end{array}$ \\
\hline
\end{tabular}

a. Dependent Variable: $Y$

Dari hasil nilai regresi linier sederhana di atas dapat didirumuskan dalam model persamaan sebagai berikut :

Keterangan:

$$
\mathrm{Y}=\mathrm{a}+\mathrm{bX}
$$

$\mathrm{Y}=$ Variabel dependen (Publikasi Pembagian Dividen)

$\mathrm{a}=$ Konstanta

$\mathrm{b}=$ koefisien regresi

$\mathrm{X}=$ Variabel independen (Abnormal Return)

Maka :

$$
Y=-2,406+0,290 X
$$

Adapun interpretasi dari persamaan tersebut adalah sebagai berikut : 
Dari persamaan di atas nilai -2,406 merupakan konstanta, 0,290 merupakan koefisien regresi dapat di artikan jika return sekuritas atau portofolio bergerak naik (turun) sama besarnya mengikuti dengan return pasar.

Dalam hal ini uji t sangat dibutuhkan untuk menguji signifikan konstanta dan varibel bebas. Persamaan regresi yang telah diperoleh sebelumnya akan di uji apakah variabel bebas dapat dijadikan sebagai variabel untuk mmelihat pengaruh dari publikasi pembagian dividen. Dengan hipotesis sebagai berikut:

Ha: Terdapat pengaruh

Ho: Tidak ada pengaruh

Dengan keriteria pengambilan keputusan sebagai berukut:

jika t hitung $<\mathrm{t}$ tabel maka $\mathrm{HO}$ diterima, nilai probabilitas $>0.05$

jika t hitung $>$ t tabel maka $\mathrm{H} 1$ di tolak, nilai probabilitas $<0.05$

Dari hasil perhitungan diperoleh nilai t hitung 0,318 dan t tabel 2,160. jadi $0,318<$ 2,160 dan nilai signifikan atau probabilitas $0,764>0,05$. maka berdasarkan pengujian statistik HO diterima. Jadi publikasi pembagian deviden tidak ada pengaruh terhadap reaksi pasar.

\section{Pengujian Data Normalitas}

Uji hipotesis dalam penelitian ini menggunakan Paired Sample t-test jika data terdistribusi normal. Uji normalitas data dilakukan dengan menggunakan One Sample Kolmogorov -Smirnov yaitu dengan ketentuan apabila nilai signifikan diatas 0,05 maka data terdistribusi normal. Sedangkan jika hasil One Sample Kolmogorov Smirnov menunjukkan nilai signifikan dibawah 0,005 maka data tidak terdistribusi normal.

Tabel di bawah ini melihatkan hasil uji normalitas data variabel Average Abnormal Return sebelum dan sesudah pengumuman dividen.

Tabel Hasil Pengujian Normalitas Variabel Average Abnormal Return

\begin{tabular}{|l|r|r|c|}
\hline \multirow{2}{*}{ Variabel } & \multicolumn{3}{|c|}{ Kolmogorov-Smirnov } \\
\cline { 2 - 4 } & Statistic & df & Sig. \\
\hline AAR Sebelum & 0,249 & 7 & $0,200^{*}$ \\
AAR Sesudah & 0,213 & 7 & $0,200^{*}$ \\
\hline
\end{tabular}

Terlihat hasil dari uji normalitas pada tabel diatas menunjukan bahwa data terdistribusi normal, hal itu bisa dilihat dari Signifikansi data Average Abnormal Return Sebelum Sebesar 0,200 begitupun dengan data signifikansi dari data Average Abnormal Return Sesudah sebesar 0,200, dengan ini ketentuan uji normalitas One Sample Kolmogorov Smirnov nilai Signifikansi di atas 0,05 terpenuhi sehingga dapat dilakukan pengujian Paired Sample t-test.

\section{Pengujian Hipotesis (Paired Sample t-test)}

Reaksi pasar terhadap pengumuman dividen dapat di dilihat dengan pengujian Paired Sample t-test. Dalam pengujian ini kriteria penerimaan hipotesi ini apabila nilai nilai signifikansi atau $\alpha<0,05$ maka hipotesis terdukung, jika nilai signifikansi atau $\alpha>0,05$ maka hipotesis tidak terdukung. 
Abnormal return menjadi variabel penelitian pada uji hipotesis ini yang diperoleh dari selisih Actual Return saham pada pengamatan dengan Expected Return pada periode pengamatan, setelah itu menghitung Average Abnormal Return Seluruh pada Periode. Average Abnormal Return menjadi sample data dalam perhitungan Paired Sample $t$-test..Hasil dari Perhitungan pada penelitian ini disajikan dalam tabel berikut ini:

\section{Tabel Hasil Paired Sample t-test Variabel Penelitian}

\begin{tabular}{|c|c|c|c|c|c|c|c|c|c|}
\hline \multicolumn{10}{|c|}{ Paired Samples Test } \\
\hline & & & & ed Difference & & & & & \\
\hline & & \multirow[b]{2}{*}{ Mean } & \multirow{2}{*}{$\begin{array}{c}\text { Std. } \\
\text { Deviation }\end{array}$} & \multirow{2}{*}{$\begin{array}{c}\text { Std. Error } \\
\text { Mean }\end{array}$} & \multicolumn{2}{|c|}{$\begin{array}{c}95 \% \text { Confidence Interval } \\
\text { of the Difference }\end{array}$} & \multirow[b]{2}{*}{$\tau$} & \multirow[b]{2}{*}{$\mathrm{df}$} & \multirow{2}{*}{$\begin{array}{l}\text { Sig. } \\
(2- \\
\text { tailed) }\end{array}$} \\
\hline & & & & & Lower & Upper & & & \\
\hline Pair 1 & $\begin{array}{l}\text { Sesudah - } \\
\text { Sebelum }\end{array}$ & -.00149857 & .00924785 & .00349536 & -.01005141 & .00705426 &,- 429 & 6 & 683 \\
\hline
\end{tabular}

Sumber : (BEl, data diolah, 2020)

Dapat dilihat bahwah nilai sig. (2-tailed) pada tabel Paired Sample t-test sebesar 0,683 dan hal ini menunjukkan nilai signifikansi atau $\alpha>0,05$ maka hipotesis tidak terdukung atau dalam hal ini tidak signifikan pengaruhnya terhadap reaksi pasar.

\section{E. PEMBAHASAN}

\section{1) Abnormal Return}

Tahapan pertama untuk menghitung abnormal return ialah menghitung actual return atau return realisasi, yaitu merupakan keuntungan yang sesungguhnya terjadi atau keuntungan yang telah terjadi dengan perbandingan dari harga saham pada saat $t(P, t)$ dikurangi harga saham pada saat $t-1 \quad(P, t-1)$ ditambah dengan dividen pada saat $t$, kemudian dibagi dengan harga saham pada saat $t-1(P, t-1)$ dan pada penelitian ini data actual return diolah mengunakan Microsoft Excel.

Selanjutnya menghitung Excpected return dalam penelitian ini menggunakan Market Model diperoleh dengan cara intercept pada periode ke t ditambah slope ( harga keseimbangan resiko di pasar) pada periode ke $t$ dan di kali dengan return saham pada periode ke t, pada penelitian ini data Excpected Return diolah mengunakan Microsoft Excel.

Untuk perhitungan Abnormal return diperoleh dengan cara mencari selisih antara actual return dan expected return dalam penelitian ini diolah dengan menggunakan Microsoft Excel.

\section{2) Reaksi Pasar Terhadap Pengumuman Deviden}

Berdasarkan pengujian dari Paired Sample t-test, hasil nilai dari pengujian tersebut sebesar $\mathbf{0 , 6 8 3}$ untuk nilai signifikansi hal tersebut menunjukan bahwa nilai tersebut lebih besar dari dasar pengambilan keputuusan sebesar $\mathbf{0 , 0 5}$, sehingga hipotesis Ho diterima yaitu tidak ada pengaruh terhadap reaksi pasar sesudah publikasi dividen walaupun data pada penelitian mengalami fluktuasi selama periode pengamatan.

Begitupun dengan pengujian regresi linier sederhana diperoleh nilai t hitung sebesar 0,318 dan t tabel sebesar 2,160 $(0,318<2,160)$ dan nilai signifikan atau probabilitas $\mathbf{0 , 7 6 4}>\mathbf{0 , 0 5}$, maka berdasarkan Keriteria pengambilan keputusan, 
hipotesis $\mathrm{HO}$ diterima, dapat disimpulkan bahwa publikasi pembagian deviden tidak ada pengaruh terhadap reaksi pasar.

Hasil ini selaras dengan penelitian terdahulu dari Ninda Pangestu (2018) yang menunjukkan bahwa hasil uji paired sample t-test terdapat perbedaan yang signifikan abnormal return saham serta tidak ada perbedaan reaksi pasar antara sebelum dan sesudah pengumuman hal ini mendukung penelitian terdahulu dari Nurmala dan Ninin Non Ayu salma (2018).

\section{F. KESIMPULAN DAN SARAN}

1) Kesimpulan

Berdasarkan hasil dari perhitungan pada periode peristiwa, saat peristiwa pengumuman dividen berlangsung diperoleh pada saat t-7 nilai rata-rata abnormal return sebesar 0.002 dan terjadi penurunan dari $\mathrm{t}-6$ sebesar $-0,002$ sampai dengan $\mathrm{t}-2$ sebesar $-0,007$, pada $\mathrm{t}-2$ dan $\mathrm{t}-1$ mengalami fluktuatif dan pada saat pengumuman dividen t 0 mengalami penurunan sebasar $-0,008$ sampai dengan $t+3$, terjadi kenaikan pada $t+4$ sebesar 0,005 , serta hasil yang fluktuatif terjadi $t+5$ sampai dengan $t+7$. Hasil menunjukkan tidak ada pengaruh reaksi dari investor terhadap penumuman dividen.

\section{2) Saran}

Berdasarkan dari kesimpulan yang ada, peneliti memberikan saran bagi investor untuk menganalisis lebih lanjut suatu informasi yang dipublikasikan oleh emiten atau perusahaan, mengunakan informasi yang lebih luas seperti informasi pengumuman merger, pemecahan saham dan sebagainya. Bagi penelitian selanjutnya diharapkan melakukan pengujian event atau corparate action yang lain sebagai penelitian selanjutnya.

\section{DAFTAR PUSTAKA}

Anindhita, Ghalih. 2010. Analisis Reaksi Pasar Atas Pengumuman Dividen Sebelum Dan Sesudah Ex-Dividend Date. Semarang: Badan Penerbit Universitas Diponegoro.

Baridwan, Zaki. 2019. Intermediate Accounting, Edisi 7, BPFE, UGM, Yogyakarta.

Hartono, Jogiyanto. 2016. Teori Portofolio dan Analisis Investasi. Edisi Kesebelas. Yogyakarta : BPFE-Yogyakarta.

Hendra, 2007. Analisis Pengaruh Pengumuman Dividen Naik Terhadap Harga Saham. Yokyakarta: Badan Penerbit Universitas sananta Dharma Yokyakarta.

Mediyanto, Martiyan Eka. 2015. Pengaruh Stock Split Terhadap Abnormal Return dan Volume Perdagangan. Artikel IImiah Mahasiswa Universitas Jember.

Nurmala dan Non Ayu Salma, Ninin, 2018. Reaksi Pasar Terhadap Pengumuman Right Issue Di Bursa Efek Indonesia. Jurnal Manajemen dan Bisnis Sriwijaya, Vo.13 No.3 September 2015 
Pangestu, Ninda. 2018. Analisis Abnormal Return Saham, Aktivitas Volume Perdagangan, Dan Bid Ask Spread Sebelum Dan Sesudah Stock Split. Lampung: Badan Penerbit Universitas Lampung.

Sugiyono. 2013. Metode Penelitian Kuantitatif, Kualitatif, dan Kombinasi (Mixed Methods). Bandung : Badan Penerbit Alfabeta.

Sunariyah, 2011, Pengantar Pengetahuan Pasar Modal, Edisi Keenam, UPP AMP YKPN, Yogyakarta.

Whardanih, Elisa. 2009. Pengaruh Pengumuman Deviden Tunai Terhadap Perubahan Harga Saham Dan Volume Perdagangan Saham Pada Perusahaan Publik Di Bursa Efek Indonesia. Surakarta: Badan Penerbit Universitas Muhammadiyah.

http://www.idx.co.id

https://finance.yahoo.com/

https://www.ksei.co.id/ 